\title{
The conceptualisation of sin in the Gospel of Matthew
}

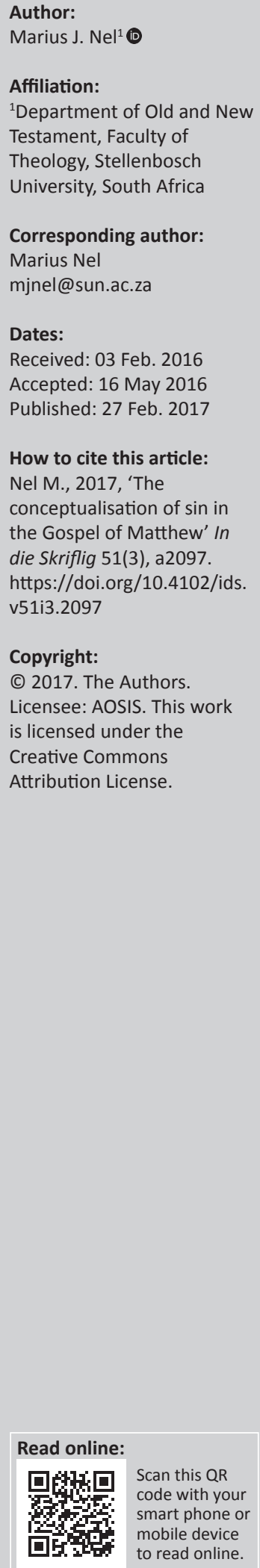

This article focuses on the conceptualisation of sin in the Gospel according to Matthew. It builds on the work of Nathan Eubank who describes the sin of Israel as a debt to be repaid by analysing other Matthean metaphors of sin as a substance, stain and stumbling block. The article argues that the replacement of the conceptualisation of sin as a burden by that of a debt in Second Temple Judaism has not fully occurred in Matthew. It also argues that the metaphor of sin as a burden is not the same as that of a stain, for the latter evokes the complex relationship between sin and impurity. It is suggested that Matthew's use of specific metaphors for sin was not just due to Aramaic linguistic influences on Second Temple Judaism, but also to the sociohistorical context in which his Gospel originated. In this regard it is important to note that Matthew's conceptualisation of Israel's sin as a debt not only refers to their sin in the period before the birth of Jesus, but also to their rejection of him as the Messiah.

\section{Introduction}

The focus of this article is on the conceptualisation of sin in the Gospel according to Matthew. The Greek-English lexicon based on semantic domains by Louw and Nida (1989:742) describe semantic domain 88 (Moral and Ethical Qualities and Related Behaviour) as being 'unusually large' with subdomains O-L' (negative qualities of human behaviour) comprising 213 lexical items. Out of these items, 29 (88.289-318) refer to sin as an action or state (subdomain Sin, Wrongdoing, Guilt). While not all of these lexical items are used by Matthew, his vocabulary for sin or specific moral and ethical behaviour, which can be described as being sinful, remains extensive (cf. Table 1).

It is evident from Table 1 that lexical items, which refer to sin, permeate the Gospel of Matthew. Furthermore, if it is taken into consideration that Matthew often refers to sin or sinners in a

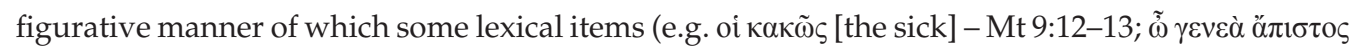

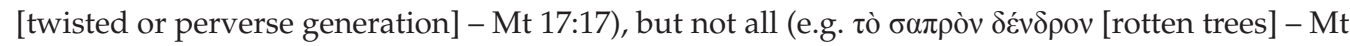
7:17-18), are included in domain 88, then references to sin are even more pervasive in his Gospel than suggested by Table 1.

The focus of this article is, however, not on individual sins (i.e. what qualities or behaviour transgress Matthew's understanding of the Law), but rather on sin as a concept. It is not a lexical or semantic study of Matthew's terms for sin in Table 1 or of specifics sins, ${ }^{1}$ but rather an attempt to grasp how he conceptualises sin within his socio-historical context. The article will therefore investigate Matthew's metaphors for sin in order to understand the social dynamics and theology underlying the first Gospel. It will first engage with the recent studies of Nathan Eubank (2013) and Rikard Roitto (2015), who both have utilised the work of Gary Anderson (2009) on the development of the concept of sin in the biblical text in order to further analyse Matthew's metaphors for sin. Thereafter the conceptualisation of sin, as a particular kind of substance (a stain and a stumbling block), will be discussed.

\section{Sin as a burden or a debt}

The study of sin has received a renewed impetus with the publication of the influential study, SinA History, by Gary Anderson (2009). The point of departure of Anderson's study (2009:5-6) is the argument of Paul Ricoeur (1967) in his seminal work The Symbolism of Evil that we have no direct or unmediated access to the semantic content of ideas such as sin and error or their rectification. All we have at our disposal are the metaphors that serve as the building blocks for larger narrative complexes in which these ideas occur. To understand what sin is one must therefore, according to Anderson, begin with the terminology for sin used by a particular writer and attempt to grasp the

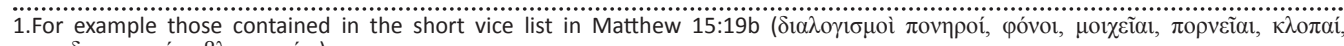

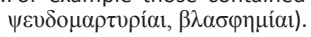


TABLE 1: Lexical items of subdomain Sin, Wrongdoing, Guilt occurring in Matthew.

\begin{tabular}{|c|c|c|c|}
\hline Reference number & Lexical item & Definition & Matthew \\
\hline 88.289 & $\dot{\alpha} \mu \alpha \rho \tau \dot{\alpha} v \omega ; \dot{\alpha} \mu \alpha \rho \tau \tilde{i}^{\mathrm{a}}, \alpha \varsigma$ & $\begin{array}{l}\text { To act contrary to the will and law of God 'to sin, to engage in } \\
\text { wrongdoing, sin'. }\end{array}$ & $18: 15,21 ; 27: 4$ \\
\hline 88.294 & 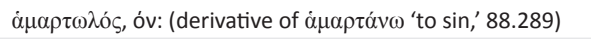 & Pertaining to sinful behavior - 'sinful, sinning'. & $9: 11,13 ; 11: 19 ; 26: 45$ \\
\hline 88.295 & 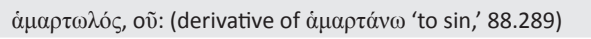 & A person who customarily sins - 'sinner, outcast'. & 9:10 \\
\hline 88.297 & $\pi \alpha \rho \alpha \dot{\pi} \tau \omega \mu \alpha$, тоৎ $n$ & $\begin{array}{l}\text { What a person has done in transgressing the will and law of God by some } \\
\text { false step or failure - 'transgression, sin'. }\end{array}$ & $6: 14,15$ \\
\hline 88.299 & 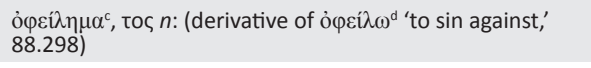 & $\begin{array}{l}\text { The moral debt incurred as the result of sin - 'offense, sin, transgression, } \\
\text { guilt'. } \ddot{\alpha} \varphi \varepsilon \varsigma \dot{\eta} \mu \tilde{i} v \tau \dot{\alpha} \text { ó } \varphi \varepsilon \imath \lambda \eta \dot{\eta} \mu \alpha \alpha \dot{\eta} \mu \tilde{\omega} v \text { 'forgive us our sins'. }\end{array}$ & $6: 12$ \\
\hline 88.300 & $\begin{array}{l}\text { ò } \varphi \varepsilon 1 \lambda \dot{\varepsilon} \tau \eta \varsigma^{c} \text {, ou } m \text { : (derivative of ỏ } \varphi \varepsilon i ́ \lambda \omega^{d} \text { 'to sin against,' } \\
88.298 \text { ) }\end{array}$ & One who commits sin and thus incurs a moral debt - 'sinner, offender'. & $6: 12$ \\
\hline 88.304 & $\begin{array}{l}\sigma K \alpha v \delta \alpha \lambda i \zeta \omega^{\mathrm{b}} \text { (a figurative extension of meaning of } \\
\sigma \kappa \alpha v \delta \alpha \lambda i \zeta \omega \text { 'to cause to stumble,' not occurring in the NT) }\end{array}$ & $\begin{array}{l}\text { To cause to sin, with the probable implication of providing some special } \\
\text { circumstances which contribute to such behavior - 'to cause to sin'. }\end{array}$ & $\begin{array}{l}5: 29,30 ; 18: 6,8,9 \\
24: 10 ; 26: 31,33\end{array}$ \\
\hline 88.306 & 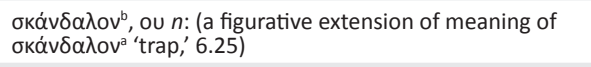 & $\begin{array}{l}\text { That which or one who causes someone to } \sin -\text { 'that which causes } \\
\text { someone to sin, one who causes someone to sin'. }\end{array}$ & $13: 41 ; 18: 7$ \\
\hline 88.308 & 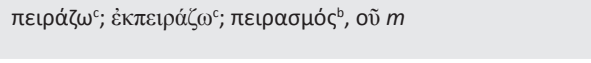 & $\begin{array}{l}\text { To endeavor or attempt to cause someone to } \sin \text { - 'to tempt, to trap, to } \\
\text { lead into temptation, temptation'. }\end{array}$ & $4: 1,3$ \\
\hline 88.310 & $\dot{\alpha} \mu \alpha \rho \tau \tau^{c} \alpha^{c}, \alpha \varsigma f$ & The moral consequence of having sinned - 'guilt, sin'. & $\begin{array}{l}1: 21 ; 3: 6 ; 9: 2,5,6 \\
\quad 12: 31 ; 26: 28\end{array}$ \\
\hline 88.312 & 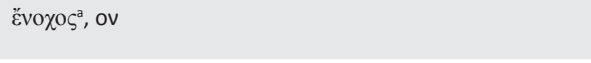 & $\begin{array}{l}\text { Pertaining to being guilty for having done wrong (primarily a legal term) } \\
\text { - 'guilty, liable'. }\end{array}$ & $5: 21$ \\
\hline 88.313 & $\varepsilon ̈ v o \chi o \zeta^{\mathrm{b}}$, ov & $\begin{array}{l}\text { Pertaining to being guilty and thus deserving some particular penalty - } \\
\text { 'guilty and deserving, guilty and punishable by'. }\end{array}$ & $5: 22 ; 26: 66$ \\
\hline
\end{tabular}

concrete nature of the metaphors that underlie them concrete in that 'the symbol gives rise to the thought' (Ricoeur) meaning that a specific metaphor or cognitive frame gives rise to a particular understanding of sin and how it can be rectified.

In his study of the history of sin, Anderson (2009:6-9) has concluded that the concepts of forgiveness and sin, reflected in the various biblical texts, had undergone an important change in conceptualisation during the exile of Israel in Babylon. In pre-Exilic texts, sin is conceptualised as a substance that can be referred to as a burden to be lifted or a stain to be removed as is apparent from the use of the Hebrew נשא (literally 'lift' or 'carry') with the meaning of 'to forgive' when used in regard to sin. According to Anderson, sin and forgiveness appear to have been cognitively modelled on the concrete human experience of burdens. When Israel, however, came into contact with Aramaic during their Babylonian exile, they adopted Aramaic idioms for sin which were modelled on a monetary debt to be paid instead of a burden to be lifted. ${ }^{2}$ This linguistic and idiomatic shift fundamentally changed how Israel understood both sin and the remedy for it. Forgiveness was no longer conceptualised as the removal of a substance, but rather as the remittance of a debt. The new metaphor of $\sin$ as a debt that must be remitted, instead of a burden to be lifted - also resulted in new ways of thinking about forgiveness. ${ }^{3}$ If the dominant metaphor for sin is that of a debt, which needs to be repaid, the concrete nature of the metaphor - economic debts can, for example, increase or decrease - will influence the understanding thereof. The idea thus arose that sin add to our debt to God while good deeds and righteous suffering subtract from it. The potential of metaphors to produce new

\footnotetext{
2.An example of this change, according to Anderson (2009:28), is Leviticus $5: 1$ which in the Hebrew Bible, reads 'If a person should sin .. he shall bear the weight of his sin [עונו ונשיא]', but which is translated by the Aramaic Targum as 'If a person becomes obligated [by sin] ... he assumes a debt (חונשוביה ויקביל).'
}

3. Roitto (2015:142) has pointed out that Anderson is not the first to notice that sin could be seen as a substance or a debt in Jewish and Christian thinking, but that he was the first to use cognitive semantics in his analysis which has enabled him to show the implications thereof. meaning (Van der Watt 2000:13) is thus evident in the manner in which the metaphor of sin as debt shaped Israel's understanding of the nature and effect of $\sin$.

\section{Sin as debt in Matthew}

Nathan Eubank (2013) has used the above-mentioned study of Anderson in order to analyse Matthew's use of economic language in his important study, Wages of CrossBearing and Debt of Sin: The Economy of Heaven in Matthew's Gospel. Eubank follows Anderson in understanding Matthew's concept of sin as debt as reflecting the shift that had occurred during the Babylonian exile and that this conceptualisation of sin had influenced Matthew to use economic language with which to describe sin and forgiveness in his Gospel. While economic language for debt occurs in every strand of the tradition underlying Matthew's Gospel, its inclusion therein is often primarily due to his redaction of the tradition (Eubank 2013:1) ${ }^{4}$ which he undertakes in line with the general understanding of sin in Second Temple Judaism.

It is evident from Eubank's study that the metaphor of debt (cf. Mt 6:12, 13-14; 18:23-35) provides a comprehensive conceptual frame for Matthew with which to integrate a number of theological concepts. Sin is understood by Matthew, in line with other texts in early Judaism and Christianity, as incurring a debt owed to God that have to be repaid by wages earned through the performance of either good deeds ${ }^{5}$ or righteous suffering (Eubank 2013:50-52). The wages thus earned, are envisioned as being stored up in heaven (cf. the references to 'treasure in heaven') till the eschaton (Mt 6:1, 1921) when they will be used to repay the debt owed to God (cf. Mt 25:29; Eubank 2013:78). The reason for this is that God, as is the case with all creditors, expects to

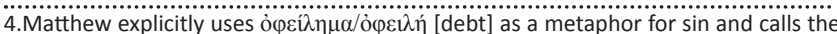

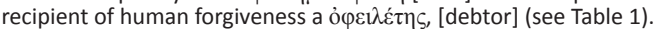

5.Almsgiving being the quintessential (cf. Mt 6:2-4), but not the only act that earns heavenly treasure (Eubank 2013:51). 
be repaid what he is owed. In Matthew 5:25-26 and 18:23-35, for example, the image of the debtor's prison, where a debtor would remain in bondage until they or their family and friends had repaid their debt, ${ }^{6}$ is used to express the notion that God expects the full repayment of debts owed to him (Eubank 2013:57-58).

Eubank's study (2013) has made it clear that economic language is interweaved with Matthew's story of Jesus. God's coming judgement is, for example, described as the

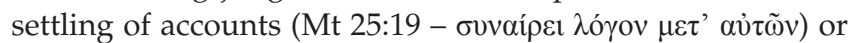
the rewarding of people for what they have done (Mt 16:27 -

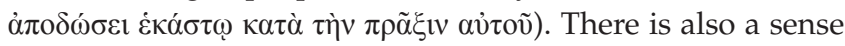
in which the collective sin of Israel (or a party thereof like the Pharisees) represents 'a measure that has been filled up'. ${ }^{7}$ In Matthew 23:32 the scribes and the Pharisees are, for example, warned by Jesus that they had 'filled the measure of their

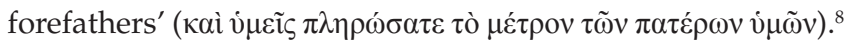
The underlying notion is that there is a preordained amount of evil that God will tolerate before he steps in to punish the perpetrators thereof (Eubank 2013:64). Their sin can thus not be understood in isolation from the larger overarching story of God's covenant with Israel and the measure of sin that has been filling up since the spilling of Abel's blood.

The Gospel of Matthew begins with the clear identification of Jesus as 'the Christ [the] son of David and [the] son of Abraham' (Mt 1:1). This identification is corroborated by the following genealogy (Mt 1:2-17) which divides the history of Israel into three sets of 14 generations: Abraham to David, David to the Babylonian exile and 14 from the exile to the advent of 'the Christ', which recapitulates God's faithfulness to Israel and the house of David from the call of Abraham till the birth of Jesus the Messiah. Importantly, the genealogy marks the key historical event before the birth of Jesus for Matthew as the exile of Israel to Babylon in 586 BCE (Eubank 2013:132), which he mentions three times (Mt 1:11-12,17) in order to structure the story of Israel's salvation by God. ${ }^{9}$ For Matthew, the end of Israel's exile is at last at hand with the advent of Jesus, the Davidic Messiah, who is God's definitive answer to the problem of Israel's sin. This claim is supported by a number of quotations from the Old Testament ${ }^{10}$ in Matthew's prologue that all deal either with the restoration of the Davidic monarchy or the end of exile (Eubank 2013:109-111).

6.The function of a debtor's prison was to coerce the family and friends of the debto to pay their outstanding debt (Eubank 2013:59). Imprisonment, in itself, did not

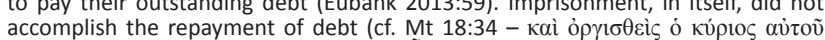

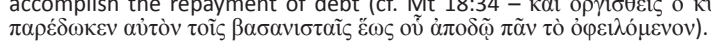

7.The idea of filling up a metaphorical cup with deeds that either add or subtract from God's wrath explains why Jesus had to be baptised. Jesus was thereby filling up his cup with righteousness. Righteousness being the wage needed to secure Israel's freedom (Eubank 2013:144).

8.Anderson (2009:75-94) states that in the Hebrew Bible, Dead Sea Scrolls and elsewhere 'to complete' or 'fulfil' refers to the point where the creditor must step in to collect his outstanding debts or, in other context, to the time when the debtor has paid his debts.

9.Before the exile David and his descendants represent the tradition of the national state as being the place of God's interaction with Israel, while the names of the following period are all of priests symbolising that the temple and not the king was the new locus of interaction (Repschinski 2006:253)

10.Compare Isaiah 7:14; Micah 5:1-3; 2 Samuel 5:2; Hosea 11:1; Jeremiah 31:15; Isaiah 40:3; 8:23-9:1
After providing the genealogy of the, as yet, unborn Jesus, his name is revealed to a dreaming Joseph by an angel to indicate that he would be his people's promised saviour from their sins through an etymological exposition of his name. ${ }^{11}$ In describing how God will restore his people from exile, Matthew again uses the notion that the return from exile is the result of Israel's debt having being paid. This idea is already evident in the later strata of the Old Testament (cf. Is $50: 1)^{12}$ and had become increasingly important in Second Temple and rabbinic literature (Eubank 2013:112-113). In line with this development, Matthew quotes both Jeremiah 31:15 and Isaiah 40:3 in his prologue to the ministry of Jesus in order to link the return from exile to the repayment of the debt of sin with the ministry of Jesus. Jeremiah 31:15 (38:15 in Septuagint - LXX), which is followed in its original literary context by the promise that there is a wage for Israel's works, ${ }^{13}$ is quoted in Matthew 2:18, while John the Baptist is described in Matthew 3:3 as the voice crying in the wilderness from Isaiah 40:3. In the preceding verse of the latter's original literary context (Is 40:2), the basis for the good news to be proclaimed to Israel is that 'her punishment is completed. For the Lord has made her pay double for all her sins' (New English Translation - NET) with the result (Is 40:10) that the Lord will come to lead his people home with 'his wages (שכר) with him, and his work before him' (Eubank 2013:114). From his appropriation of these Old Testament texts, it is apparent that Jesus is, for Matthew, the promised Messiah who would remit Israel's sin and restore her as a nation.

The question raised by the metaphor of sin as a debt for Matthew was not if Israel could earn a righteous wage from God, but if she could earn enough to repay her entire debt. That Matthew conceptualises sin as a debt to be repaid, does not suggest that he thought that sinners could also earn the full forgiveness of their sins. The rhetorical question, 'What can a person give in exchange for eternal life?' in Matthew 16:26 with the anticipated answer of 'nothing' (Eubank 2013:135), instead suggest that he did not think that sinners could earn the required wages for the remittance of the debt of their sins. This was, however, not true of Jesus. What Jesus was doing, according to Matthew, was earning wages in heaven through his righteous deeds and his death.

The wage Jesus had earned with his death was, however, not for himself, but for others and it is through the wage-earning gift of his life that Jesus would ultimately save his people from their sins (Mt 20:28; Eubank 2013:157-158). It is for this reason that the Matthean Jesus describes his life as a $\lambda v i \tau \rho v$

11. While the etymology of Jesus' name (Mt 1:21) provides neither the modus of the promised salvation, nor the precise nature of the sin to be remitted, it does foreshadow the declaration by Jesus $(26: 28)$ that he would save his people from their sins by giving his life (Repschinski 2006:248-267). The inclusio between the naming of Jesus and his declaration that he would save his people from their sins emphasise the importance of the theme the forgiveness of sin in Matthew (Nolland 2005:380).

12.'Thus says the Lord: Where is your mother's bill of divorce with which I put her away? Or which of my creditors is it to whom I have sold you? No, because of your sins you were sold, and for your transgressions your mother was put away' (Is 50:1-NRSV).

13.'Let your voice stop weeping, and your eyes from tears, because there is a wage

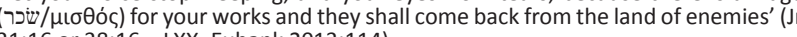
31:16 or 38:16 - LXX; Eubank 2013:114) 
[price of release, ransom] - a term which always refers to some sort of payment or exchange through which Israel's debts were to be remitted (Eubank 2013:150-151). The term

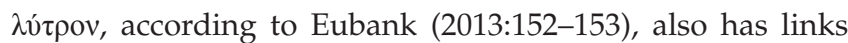
with the abovementioned end of exile theme. In Exodus 6:6 God, for example, commands Moses to tell the Israelites that 'I will ransom ( $\lambda \nu \tau \rho \omega ́ \sigma o \mu \alpha$ - LXX) you with uplifted arm' while in Micah 6:4,'For I brought you from the land of Egypt and ransomed ( $\dot{\varepsilon} \lambda v \tau \rho \omega \sigma \alpha \dot{\mu} \mu \nu$ - LXX) you from the house of slavery', God recalls the Exodus ending due to a ransom being paid. Prophecies of the end of future exiles similarly use ransom language. In the promise of restoration in Isaiah

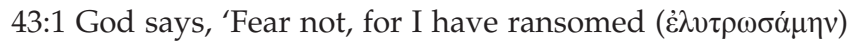
you' while Jeremiah 31:11 (38:11 in LXX) states that 'the Lord has ransomed ( $\dot{\varepsilon} \lambda v \tau \rho \omega ́ \sigma \alpha \tau$ ) Jacob and has delivered him from stronger hands'. Similarly, Micah 4:10 promises that 'the Lord your God will ransom ( $\dot{\varepsilon} \lambda v \tau \rho \omega \sigma \alpha ́ \mu \eta v-L X X)$ you from the hand of your enemies'.

Other examples of economic terms underlying Matthew's understanding of sin are to be found in Matthew 26:28 where Jesus, during his last supper, describes his blood as 'the blood of the covenant which is poured out for many for the

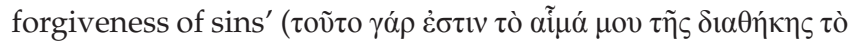

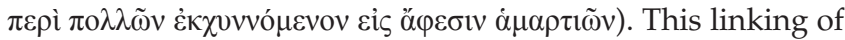
Jesus' words about the blood of the covenant to the forgiveness of sins is unique to Matthew (Eubank 2013:175). The phrase blood of the covenant occurs in the Old Testament during the covenant ceremony at Sinai in Exodus 24:8 where Moses takes the blood from the offerings of the 12 tribes and throws half of it on the altar and half on the people proclaiming 'Behold the blood of the covenant which the Lord has made with you in accordance with all these words' (New Revised Standard Version - NRSV). Exodus 24:8 is cited in Zechariah 9:9-12 which states that the redemption from captivity (exile) is a 'repayment' and that it will happen 'by the blood of the covenant'. According to Eubanks (2013:174), the implication of Zechariah's words is that God's repayment of Israel's debt and her restoration as nation is due to the covenant that was cut at Sinai. It is these words in Zechariah 9:9, which Matthew 21:5 cites when Jesus enters Jerusalem and thereby evoking the wider context thereof (Zch 9:10-12), ${ }^{14}$ that mention the ransom God has paid for his people (Eubank 2013:171-173). The themes of covenant, exile, blood, sin and the death of Jesus are thus all linked to each other for Matthew.

Eubank's argument that Matthew uses economic language and the metaphor of debt, in particular, in order to describe how Jesus saves his people from their sins is a compelling one. The value of Eubank's analysis and that it integrates Matthean material which, in the past, have caused considerable interpretive problems for exegetes (e.g. the notion of earning a reward or wage from God) by locating Matthew's ethics of forgiveness within the specific

14. Eubank (2013.173) translates w... in Zechariah 9.12 as 'repay' instead of 'restore' (cf. NRSV), because it better fits the context of both Zechariah 9 and the quoted Exodus 21:34, and is in line with the Septuagintal interpretation thereof (בישא

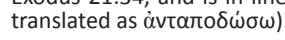

socio-historical context of Second Temple Judaism and its understanding of the story of Israel. This context highlights important aspects of his understanding of sin like the collective and covenantal dimension thereof which had resulted in the exile of Israel. While N.T. Wright (1996:268) claims that Israel considered herself still to be in exile due to the continuing Roman occupation of the land is contentious, ${ }^{15}$ it does appear as if Matthew's repeated references to the Babylonian exile in the genealogy of Jesus indicates that, for him, Israel remained on the wrong side of the river Jordan (Schreiner 2008:510) in that she had not yet repented from the sin which had resulted in her exile to Babylon. For Matthew the period of Israel's exile finally comes to an end with the birth of Jesus who he identifies as the one who would save his people from their sins (Eloff 2008:93). It is this emphasis on the exile by Matthew which clearly marks the entire history of Israel's ancestors, kings and priest up to the birth of Jesus as one in need of redemption (Repschinski 2006:253). There is thus no reason for Matthew to list the specific sins of Israel which had resulted in her being taken into exile. What needed to be understood by his readers was that Israel's sins of the past had increased her debt burden to the point that God had intervened in the history of Israel.

The relationship between Matthew's context and the metaphors for sins he uses to express what was wrong with the world, are theologically significant. According to Van der Watt (2000:12), the socio-historical framework within which a metaphor originated, plays an important role in the continued cognitive and emotive functioning thereof. It is therefore plausible that the metaphors used by Matthew gained their currency in his community due to their resonance with the concrete experience of his intended audience and not only due to their exposure to Aramaic, in other words, that the experience of the growing debt burden in 1st-century Palestine led to their use by the Matthean Jesus. ${ }^{16}$

\section{Sin as substance in Matthew}

Eubank's study of the metaphoric use of economic language in Matthew to describe sin can also be expanded on in light of the critique of Anderson's work on which it is based. For example, Rikard Roitto (2015:143), while accepting Anderson's analysis (2009:27) as compelling, differs from his conclusion that the metaphoric understanding of $\sin$ as a substance was replaced by the metaphor of $\sin$ as a debt. Roitto instead argues that, while the metaphor of debt had become more prevalent in post-Exilic texts, the metaphor of substance continued to be used in both Judaism (Sir 23:10; 38:10; 1 Macc 1:48; Philo, Cher. 28:91-95; Jub 9:15; 1QS 3:13-14) and Christianity (Jn 1:29; 2 Tm 3:6; Heb 1:3; 9:28; 10:2, 4, 11; 12:1, 4; Ja 3:6; 1 Pt 4:8; 2 Pt 1:9; 1 Jn 1:7, 9; Rv 7:14; 22:14). This dual use of metaphors for sin was made possible by the polyvalence of the Greek verb ápín $\mu$. Roitto (2015:137) therefore does not accept the placement of the translation of

15.The equation that 'forgiveness of sins' means 'return of exile' (Wright 1996:268) is, however, too simplistic (Eubank 2013:112).

16.For a discussion of the role of debt in Matthew and 1st-century Palestine, see $\mathrm{Nel}$ (2013:89-98). 


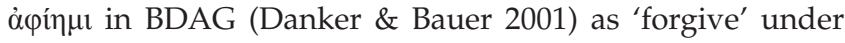
section 2 ('to release from legal or moral obligations or consequence'), because it assumes that forgiveness in early Christian texts is always modelled on remission of debt. In this regard LSJ (Liddell \& Scott 2004) differs from BDAG, because it lists the basic meanings of $\alpha \varphi$ in $\mu$ us 'sent forth' (or 'sent away') as well as the sense of 'remit' under section A. II.2.c (Roitto 2015:146-147). Importantly the various usages of $\dot{\alpha} \varphi$ í $\mu$ listed by LSJ can accommodate two different cognitions of the forgiveness of sin. The first 'A sender sends / lets an object on a trajectory' can be used to describe the removal of the substance of sin, and the construction. 'A benefactor remits a bond/debt/obligation for a person' can be used to describe the remission of the debt of $\sin$ (Roitto 2015:147).

In light of the polyvalence of $\dot{\alpha} \varphi$ í $\mu$ it comes as no surprise that both metaphors for sin as a debt and a substance occur in Matthew. Eubank's specific focus (2013) on the metaphor of $\sin$ as debt means that he, however, does not include in his study texts in Matthew which do not use economic language to refer to sin. The healing of the paralytic in Matthew 9:1-8, for example, treats $\sin$ as a substance to be removed and not as a debt to be remitted (Roitto 2015:148-149). There is, however, some differentiation between the use of the different metaphors for sin in that, whereas God can be the forgiving agent in both, humans can only be the agent in the debt metaphor. According to Roitto (2015:149), Matthew thus avoids describing interpersonal forgiveness as the removal of a substance $(6: 12,14-15 ; 18: 20-35)$. For him only God has the power to remove the substance of sin. Human agents can and must, however, forgive the moral debt of those who had wronged them like God does. ${ }^{17}$

Matthew's understanding of sin as a substance suggests that it should also be taken into consideration that his references to sin and salvation should not always be taken as being merely metaphorical in nature. The a fortiori argument of Jesus in Matthew 9:4-6, for example, presupposes the commonly held belief that sins and disease were linked..$^{18}$ The forgiveness of sin therefore also necessitated the healing of the paralytic (Mt 9:7). In this case both sin and forgiveness are not only metaphorical in nature. The same could be true of other texts

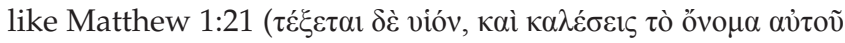

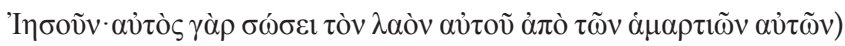
in which the reference to Jesus saving his people from their sins can be read as that the Matthean messiah did not intend

\footnotetext{
17.The addition that the authority of Jesus has been given to people in Matthew 9:8

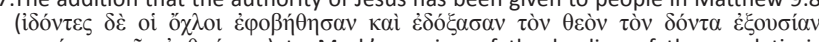

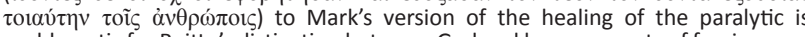
problematic for Roitto's distinction between God and human agents of forgiveness, because it is not the debt metaphor, but the substance one that is presupposed. The surprising conclusio of Matthew 9:1-8, which assumes that the same authority has been given to people, is therefore understood by Roitto as that the authority of Jesus to forgive $\sin$ as a substance is only to be mediated by them. The power to forgive sin as a substance is thus not given to people. It is, however, a question whether God's power to forgive the substance of sins is not specifically extended whether God's power to forgive the substance of sins is not specifically extended the case, then the differentiation between God and humans, being the subjects of the forgiveness of the substance of sin, does not hold.

18.Compare Leviticus 26:14-16; Deuteronomium 28:21-22; Psalm 38:4; 40:12-13; Proverbs 5:22; Wisdom 11:15-16; Romans 5:12-8:39; 11 Qumran Psalms Scroll 19:13-16; 2 Chronicles 21:15, 18-19; John 5:14; 9:2; 1 Corinthians 11:30 (Nolland 19:13-16; 2 Co5:380).
}

to save his people from their political oppression, but merely from their sins. But if it was their sins, which had led to their subjugation and oppression (i.e. their exile), the possibility arises that Matthew's readers would have assumed that if Jesus had indeed addressed the cause of their oppression their $\sin$-he had also changed their socio-political reality. ${ }^{19}$ That, like the forgiveness of the sin of the paralytic had physically restored him (Mt 9:1-8), their political freedom would be re-established.

The work of Eubank on Israel's accumulated debt for her past sins can be further expanded if it is taken into consideration that Matthew's Gospel does not only engage with Israel's past. It also engages with her future, and it is in this regard that it can be asked if Israel's negative response to Jesus had not added to their burden. Matthew 27:25 (каì

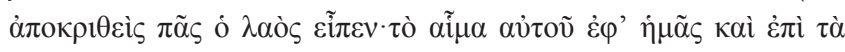
$\tau \varepsilon ́ \kappa v \alpha \dot{\eta} \mu \tilde{\omega} v)$ for example implies that Israel wittingly took on the burden of Jesus' death. It can thus be argued that Matthew

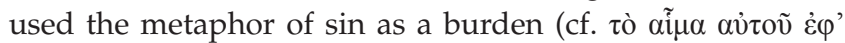

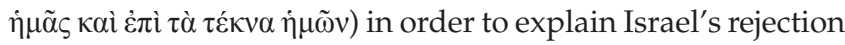
and his community's acceptance by God. ${ }^{20}$ For, according to Matthew, Israel will be judged by God (Mt 13:41,49) like all who break the Law and cause others to sin, not only for their conduct in general, but especially for rejecting the Messiah (Mt 21:33-46). ${ }^{21}$ The death of Jesus thus has a divergent effect. For the authorities in Jerusalem, who had rejected Jesus, it had added to their burden, but for those who accepted his message it resulted in the setting aside of their burden.

\section{Sin as a stain and stumbling block}

While Roitto is correct in claiming that both the debt and the burden metaphors for sin were in use in Early Christianity, and therefore need to be taken into consideration in describing Matthew's conceptualisation of sin, it is also important to note the criticism of Couenhoven (2011:194) on Anderson (2009) whose work undergirds that of Eubank and Roitto, ${ }^{22}$ that he ignores metaphors for sin other than debt or weight: what of stain or uncleanliness, evidenced in numerous Scriptural injunctions to wash? What of the connections between sin and chaos, boundary crossing,

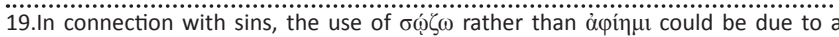
wordplay on the name of Jesus (Repschinski 2006:255). This wordplay results in every mention of the name of Jesus in Matthew serving as a reminder to the reader of his role with regard to $\sin$. It is, however, used with regard to physical afflictions (Mt 8:25; 9:21-22).

20.The Roman representative, Pilate, is depicted by Matthew as conducting a failed cleansing ritual in order to transfer his guilt to Israel (Mt 27:24 - 'I $\delta \dot{\omega} v \delta \dot{\varepsilon} \dot{o}$ $\Pi \lambda \lambda \tilde{\alpha} \tau \mathrm{c}$

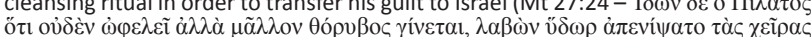

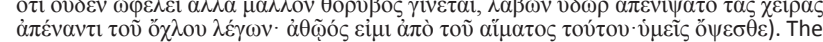

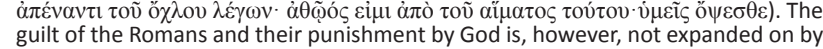
guilt of the
Matthew.

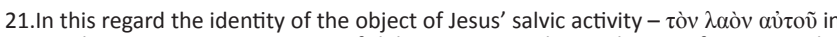
Matthew in 1:21 - is a matter of debate. Is it Israel, a proleptic reference to the church as God's new people, or a combination of both? Or had the church replaced Israel? That Matthew 1:21 is the culmination of the recapitulation of Israel's history through Jesus' genealogy suggest that Israel is primarily in view here (Cousland 2002:85; Repschinski 2006:256). Matthew's reference to the church as a new

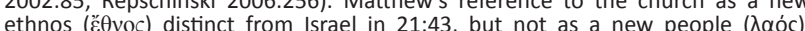
indicates that he does not understand the church to be God's new people ( $\lambda \alpha$ oo $)^{\prime}$, but rather as a new entity comprised of both (Cousland 2002:85).

22.The focus of Eubanks' study is Matthew's use of economic language for sin and that of Roitto on the polyvalence of the verb $\dot{\alpha} \varphi i_{\eta} \mu \mathrm{t}$ and the two cognitive frames of forgiveness in the Synoptic Gospels. They thus do not attempt to give a comprehensive account of all of Matthew's metaphors for sin. 
non-being, falsehood, missing the mark, falling short, or relational gulfs? ${ }^{23}$

Therefore, the possibility of Matthew's use of other metaphors than those of debt or a burden for sin as some sort of substance needs to be considered further.

\section{Sin as a stain in Matthew}

Apart from references to sin as a burden and debt in Matthew, a link is also made by him between illness, sin and impurity (e.g. $8: 2-3 ; 10: 8 ; 11: 5 ; 23: 25-26$ ) which also presupposes a metaphorical understanding of sin as a substance. The nature of the conceptualised substance is, however, communicated by a different set of metaphors for the removal of sins. In Matthew 15:10-20, Jesus, for example, specifically refers to

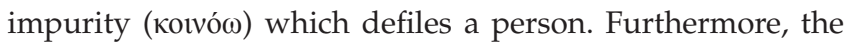
verb $\kappa \alpha \theta \alpha i \zeta \omega$ [make clean, cleanse, purify] is used by Matthew for Jesus' healing of diseases (especially leprosy) which had made a person ritually unclean (Mt 8:2, 3; 10:8; 11:5) as well as for the cleaning of the outside of a cup (Mt 23:25-26) in order to emphasise that it is not external factors that determine a person's standing before God, but their inner conviction (literally 'heart'). It is not adequate to equate the conceptualisation of sin as a stain to be removed with that of $\sin$ as a burden to be lifted, because they are not conceptually identical. The complex relationship between sin and impurity therefore needs to be clarified, because sin and impurity are also not synonymous. Nor are all references to impurity to be understood as having a uniform meaning.

Jonathan Klawans (2000) has argued that a distinction needs to be made between impurity and sin in both Ancient Judaism and the New Testament as well as between moral and ritual impurity in order to understand the relationship between sin and impurity. Ritual impurity can be conveyed by natural and bodily functions and from one person to another. This type of impurity can be removed by a bath or the passing of time. Moral impurity, on the other hand, is contracted by the performance of specific sins. It can be passed on to the land, but not to another person by physical contact. Moral impurity can also not be simply washed away and is therefore permanent (Klawans 2000:vi). While ritual impurity is unavoidable (e.g. one needs to bury the dead or procreate) and Israelites were thus allowed to become temporarily ritually impure, certain sins produced their own type of defilement - moral impurity - which had to be avoided at all cost (Klawans 2000:137).

The distinction between ritual and moral impurity is evident in Matthew 15:1-20 where Jesus is accused by the Pharisees of

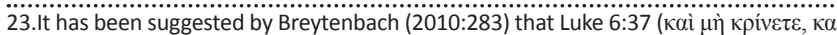

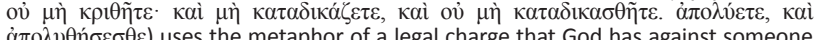
from which he or she is metaphor of a legal charge that God has against someone from which he or she is acquitted, if they have, in turn, acquitted others from the legal charges they have against him or her. This is, however, not as clear in the paralle

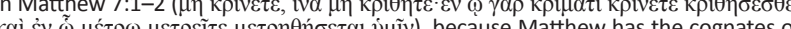

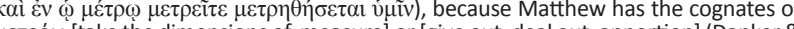
$\mu \varepsilon \tau \rho \varepsilon \omega$ [take the dimensions of, measure] or [give out, deal out, apportion] (Danker \&

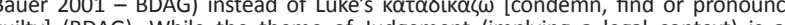
guilty] (BDAG). While the theme of Judgement (implying a legal context) is an important one in Matthew (Derrett 1984:53; Sim 1996:110-128), the metaphor of sin as a legal charge instead of a debt to be paid is, however, not expanded on. eating with unwashed hands. He responds by telling them that there is nothing outside a person which can defile them. It is rather what comes from within a person that defiles them (Mt 15:11). In terms of the distinction made by Klawans, Jesus is here dismissing an emphasis on ritual purity for one on moral purity. The short vice list that follows (Mt 15:19), specifically names a number of sins that ancient Israel also understood to be sources of moral defilement. It should be noted that Jesus is not necessarily dismissing the relevance of ritual purity completely in this instance, because the 'not ... but' antithesis in Matthew 15:11 need not be understood as 'either ... or' because it could have the force of 'more important than'. ${ }^{24}$ If this is the case, Jesus is prioritising moral purity above ritual purity instead of dismissing the latter (Klawans 2000:149).

While it is unclear from the preceding discussion if the Matthean Jesus is denying or reprioritising the role of ritual purity, it is clear that the link between moral purity and sin supports the notion that sin could also be metaphorically understood as a stain to be removed or cleansed. ${ }^{25}$ Therefore, it is apparent that Matthew used other metaphors than that of a debt or a burden for sin. At times more than one conceptual frame may also underlie Matthew's narrative of events and thereby emphasising the seriousness of sin for him. Not only are Israel, for example, called on by John the Baptist to repent from their sins and to purify themselves by being baptised by him in the Jordan (Mt 3:6) by using the metaphor of sin as a substance to be cleansed, but can Jesus" baptism also be understood as fulfilling all righteousness in reference to the metaphor of sin as a debt that needs to be paid by righteous deeds. ${ }^{26}$

\section{Sin as a stumbling block in Matthew}

Another recurrent metaphor for sin to consider in Matthew is based on the notion of 'causing someone to stumble' $(\sigma \kappa \alpha v \delta \alpha \lambda i \zeta \omega)$ or of being 'a stumbling block' or 'obstacle' ( $\sigma \kappa \alpha ́ v \delta \alpha \lambda \mathrm{ov}$ ) (France 2007:205). ${ }^{27}$ While it is primarily the use of Hebrew, Aramaic and Greek verbs, which describe how sin should be dealt with in the biblical text and not the terminology for the sins themselves that guide Anderson, Eubanks and Roitto in their analysis of the metaphors for sin as a debt or a burden, the conceptualisation of $\sin$ as a

24.Jesus' statement in Mark $2: 17$-that 'I came not to call the righteous, but sinners', for example, does not mean that he only called sinners.

25.Further support for the metaphoric understanding of $\sin$ as a stain or substance to be removed, is provided by the numerous cultic terms used in other documents of the New Testament in regard to sin (Breytenbach 2010:293). Sin as a substance

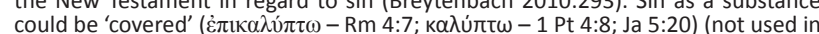

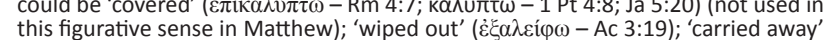

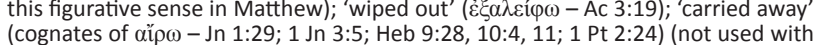

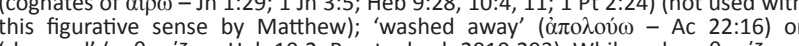

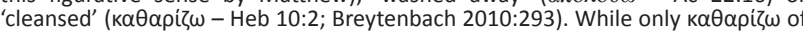
these examples occurs in Matthew (cf. 8:2, 3; 10:8; 11:5; 23:25; 23:26), the metaphor of a stain for sin must still be considered to be a plausible one.

26.It should, however, be noted that while it is clear that the intention of John's baptism in Mark was to purify individuals from moral defilement rather than to ritually purify them (Klawans 2000:141), this is less clear in Matthew, because he has explicitly introduced Jesus' death as the foundation for the forgiveness of sins by removing the reference in Mark 1:4 that the baptism of John had resulted in the forgiveness of sins and adding it as an explanation of the meaning of the cup at the Lord's Supper (Mt 26:28).

27.Compare Matthew 5:29-30; 11:6; 13:21, 41, 53; 15:12; 16:23; 17:27; 18:6-7, 8-9; $24: 10 ; 26: 31-33$. 
stumbling block, however, metaphorises both nouns and verbs. It functions as an important metaphor in Matthew which, according to Stählin (1968:344-345), is the only Synoptic Gospel to contain all the $\sigma \kappa \alpha \dot{v} \delta \alpha \lambda$ ov or $\sigma \kappa \alpha v \delta \alpha \lambda i \zeta \omega$ sayings of Jesus ${ }^{28}$ of which some are unique to him. ${ }^{29}$ The verb $\sigma \kappa \alpha v \delta \alpha \lambda i \zeta \omega$, which occurs 14 times in Matthew (Giesen 1993a:248) and the noun $\sigma \kappa \alpha ́ v \delta \alpha \lambda o v$ which occurs five times (1993b:249), are furthermore not used in a non-metaphoric sense by Matthew. ${ }^{30}$

According to Griesen (1993a:248), $\sigma \kappa \alpha v \delta \alpha \lambda i \zeta \omega$ in the passive can mean 'does not come to faith' (e.g. the relatives of Jesus in Mt 13:57) or 'fall away from faith' (i.e. 'the many' in the end time in Mt 24:10). The metaphor of stumbling can also be used for the offence some took in the teaching of Jesus as in Matthew 11:6; 13:57; 15:12 and 17:27 where the passive verb denotes 'being offended' by a person's behaviour or teaching (France 2007:205). The Pharisees, for example, take offence in Jesus, because he exposes their purity regulations as superficial (Mt 15:12) while Jesus pays temple tax even though he is not obligated to do so in order not to give offence (Mt 17:27). The active use of the verb means 'to cause someone to fall away from faith [literally 'to stumble']' and thus potentially diverting them from the path that leads to salvation in Matthew 13:21; 18:6; 24:10 and 26:31-33 (France 2007:205). While the disciples' stumbling in Gethsemane (Mt 26:31-33) does not appear to have a terminal effect, in 5:29-30; 13:21 and 18:6-9 it leads to the final loss of salvation $(\beta \lambda \eta \theta \tilde{\eta} v \alpha$,

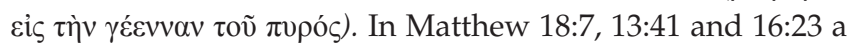
'stumbling-block' is a person or thing that gets in the way of God's saving purpose (France 2007:205) while, according to 13:41, the Son of Man will, with the eschaton, send his angels to remove all those who cause others to stumble ( $\pi \dot{\alpha} v \tau \alpha \tau \dot{\alpha}$ $\sigma \kappa \alpha ́ v \delta \alpha \lambda \alpha)$.

It is apparent from the brief analysis above that the metaphor of stumbling function as an important metaphor for the inadequate response to Jesus and his teaching as well as the result thereof for those who stumble. The lack of faith $(\dot{\alpha} \pi 1 \sigma \tau i \alpha)$ and the offence taken in Jesus $(\sigma \kappa \alpha v \delta \alpha \lambda i \zeta \omega)$ in Matthew 13:57-58 had, for example, resulted in Jesus being unable to perform mighty deeds in their midst. It also describes how it had come about that Israel was not saved from their sins by Jesus while the Matthean community had. According to Van der Watt (2000:12), a metaphor should not be limited to the use of a single word, but can consist of a sentence, a paragraph or even an entire text. The description of Jesus in Matthew 21:42-43 as the stone ( $\lambda \dot{i} \theta 0 \varsigma)$ rejected by the builders, but who has become the cornerstone ( $\varepsilon \varepsilon \varphi \alpha \lambda \eta े \nu$

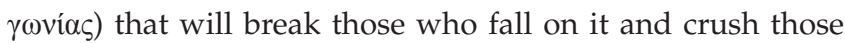
it falls on thus also needs to be taken into consideration.

28.The use of $\sigma \alpha \alpha \nu \alpha \lambda i \zeta \omega$ in Matthew $5: 30 ; 13: 21,57 ; 18: 6,8-9 ; 26: 31$ and $26: 33$ have parallels in Mark while its use in 11:6 is paralleled in Luke. Of the five occurrences of the noun $\sigma$ Kóv $\delta a \lambda o v$, only that in Matthew 18:7 occurs in Luke while it is not used at all by Mark.

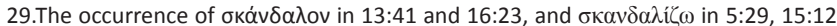
$17: 27$ and $24: 10$ are unique to Matthew.

30.In its non-metaphoric uses, the noun $\sigma \kappa \alpha ́ v \delta \alpha \lambda$ ov refers to a physical object (e.g. a

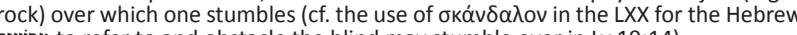
מכשול to refer to and obstacle the blind may stumble over in Lv 19:14).
Even though it does not use cognates of $\sigma \kappa \alpha ́ v \delta \alpha \lambda \circ v$ it describes how the kingdom of heaven was taken from Israel and given to those who would produce fruit (Matthew's community) by using the related images of a stone and a cornerstone.

In terms of the socio-historical framework within which a metaphor originated, and the continued cognitive and emotive functioning thereof (Van der Watt 2000:12), it is a question if the growing hostility between the Matthean community and Second Temple Judaism underlies Matthew's use of the stumbling block metaphor. ${ }^{31}$ The reference to the stones $(\lambda i \theta 0 \varsigma)$ of the future ruins of the temple in Matthew 24:2 could have served as a concrete reminder to Matthew's readers in the period after the Jewish war of the judgement which had befallen Israel due to her rejection of Jesus.

\section{Conclusion}

Although the notion of sin may have become passé in contemporary society, it is clearly a central concern for Matthew. For him sin is both deeply rooted and prevalent. It characterises both the religious leaders of Israel (cf. Mt 23) and the nation as a whole (cf. their description as being an 'adulterous generation' in Mt 16:4). In Matthew's diagnosis of society and its problems, sin is the fundamental problem that needs to be addressed. For Matthew the debt owed to God is the result of sin which is defined by the Law and in contravention of the covenant. It needs to be remitted and the contamination it causes, cleansed.

Matthew's conceptualisation of sin, as is evident in his use of a variety of metaphors, is that individual and collective sin has negatively impacted the whole covenantal history of Israel and will continue to do so till the end of the age..$^{32} \mathrm{His}$ understanding of sin as adding to the debt owed to God or as a growing burden explains how Israel's past sin and specifically her rejection of Jesus, had resulted in her rejection by God. Conversely, it also provides a conceptual frame with which to understand the manner in which Jesus had atoned for the debt of Israel in that his good deeds and righteous death had earned a heavenly wage with which to remit not his debt owed to God, but that of those who followed him.

Matthew continues to conceptualise sin as a substance. He describes sin as a stain to be removed, a burden to be lifted and a stumbling block to be avoided. His Gospel, however, also reflects the growing dominance of the conceptualisation of sin as a debt in Second Temple Judaism. This growing dominance of sin, metaphorically understood as a debt, may be due to specific socio-historical factors (e.g. the growing debt burden in Palestine) and not just to the linguistic influence of Aramaic. An important difference between Matthew's use of metaphors for sin as a debt or a substance is that while God can be the agent of the forgiveness of sin

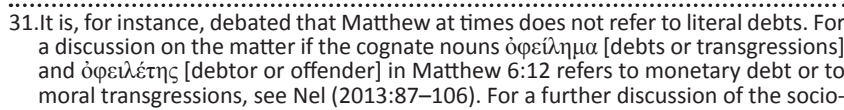
historical background of Matthew see Nel (2014a; 2014b)

32.The Gospel of Matthew closes with a reference to 'the end of the age' (28:20) 
conceptualised as a substance, human agents are only depicted as being able to forgive sins understood as a debt.

Because sin is not always merely a metaphorical concept, 'literal' expressions of sin (i.e. moral evil and oppression) and what the forgiveness thereof implies, need to be reflected on (Couenhoven 2011:196). The Roman occupation, a growing economic crisis, continuing political strife, inter- and intracommunal conflict and other social problems were, for Matthew, all the result of Israel's inability to deal with her sin. True forgiveness of sins should therefore, conversely, address all of these realities.

\section{Acknowledgements Competing interests}

The author declares that he have no financial or personal relationships which may have inappropriately influenced him in writing this article.

\section{References}

Anderson, G.A., 2009, Sin: a history, Yale University Press, New Haven.

Breytenbach, C., 2010, 'Forgiveness in Early Christian Tradition', in C. Breytenbach (ed.), Grace, reconciliation, concord the death of Christ in Graeco-Roman metaphors, pp. 279-295, Brill, Leiden.

Couenhoven, J., 2011, 'Sin: A History - By Gary A. Anderson', Modern Theology 27, 194.

Cousland, J.R.C., 2002, The crowds in the Gospel of Matthew, Brill, Leiden.

Danker, F.W. \& Bauer, W., 2001, A Greek-English Lexicon of the New Testament and Other Early Christian Literature (BDAG), 3rd edn., University of Chicago Press, Chicago.

Derrett, J.D.M., 1984, 'Palingenesia (Matthew 19.28)', Journal for the Study of the New Testament 7(20), 51-58.
Eloff, M., 2008, 'A $\pi$ ó ... ع̈ $\tilde{\omega}$ and Salvation History in Matthew's Gospel', in D.M. Gurtner \& J. Nolland (eds.), Built upon the rock: studies in the Gospel of Matthew, pp. 85-110, Eerdmans, Grand Rapids.

Eubank, N., 2013, Wages of cross-bearing and debt of sin: the economy of heaven in Matthew's gospel, De Gruyter, Berlin.

France, R.T., 2007, The Gospel of Matthew, Eerdmans, Grand Rapids.

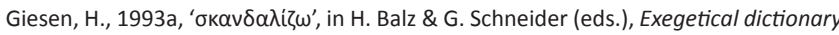
of the New Testament, vol. 3, p. 248, Eerdmans, Grand Rapids.

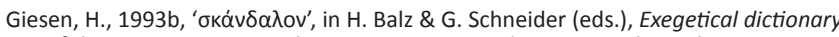
of the New Testament, vol. 3, pp. 249-250, Eerdmans, Grand Rapids.

Klawans, J., 2000, Impurity and sin in ancient Judaism, Oxford University Press, Oxford.

Liddell, H.G. \& Scott, R., 2004, A Greek-English lexicon (LSJ), Oxford University Press, Oxford.

Louw, J.P. \& Nida, E.A., 1989, Greek-English lexicon of the New Testament based on semantic domains, vol. 1, United Bible Societies, New York.

Nel, M.J., 2013, 'The forgiveness of debt in Matthew 6:12, 14-15', Neotestamentica 47(1), 87-106.

Nel, M.J., 2014a, 'Mission and ethics: Sensitivity to outsiders in Matthew', in J. Kok \& J.A. Dunne (eds.), Insiders versus outsiders: exploring the dynamic relationship between mission and ethos in the New Testament, pp. 93-112, Gorgias Press, Piscataway.

Nel, M.J., 2014b, 'The presence of religious virtuosi and non-virtuosi in the Matthean community', Nederduitse Gereformeerde Teologiese Tydskrif 55(3-4), 729-746.

Nolland, J., 2005, The Gospel of Matthew: a commentary on the Greek text, Eerdmans, Grand Rapids.

Repschinski, B., 2006, 'For he will save his people from their sins (Matthew 1:21): a christology for Christian Jews', The Catholic Biblical Quarterly 68(2), 248-267.

Ricoeur, P., 1967, The symbolism of evil, Harper \& Row, New York.

Roitto, R., 2015, 'The Polyvalence of $\dot{\alpha} \varphi$ í $\mu$ r and the Two Cognitive Frames of Forgiveness in the Synoptic Gospels', Novum Testamentum 57(2), 136-158.

Schreiner, T.R., 2008, New Testament theology: magnifying God in Christ, Baker Academic, Grand Rapids.

Sim, D.C., 1996, Apocalyptic eschatology in the Gospel of Matthew, Cambridge University Press, Cambridge.

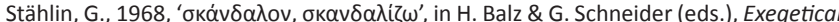
dictionary of the New Testament, vol. 3, pp. 344-345, Grand Rapids, Eerdmans.

Van der Watt, J.G., 2000, Family of the King: dynamics of metaphor in the Gospel according to John, Brill, Leiden.

Wright, N.T., 1996, Jesus and the victory of God, Fortress Press, Minneapolis. 